\title{
A EXTRAORDINÁRIA HISTÓRIA DE MARY WALKER
}

NATHANS, Sydney. To free a family: the journey of Mary Walker. Cambridge: Harvard University, 2012. 330 p.

A biografia de Mary Walker (18181872) escrita por Sydney Nathans, To free a family: the journey of Mary Walker (Libertar uma família: a jornada de Mary Walker), é um tour de force de micro-história. A obra é um produto de décadas de escavação em arquivos públicos e privados, incluindo "talvez a maior e mais rica coleção estadunidense de documentos familiares em mãos de particulares" (p. 6). Como um exemplar de micro-história, a reconstrução feita por Nathans da vida de uma pessoa até então pouco conhecida ilumina os tempos em que viveu: "na história de Mary Walker, grandes eventos na época da Guerra Civil desenrolam-se em uma escala humana íntima" (p. 254).

O biógrafo de uma pessoa escravizada de ascendência africana na América do Norte do século XVIII ou do período anterior à Guerra $\mathrm{Ci}$ vil costuma enfrentar assombrosos desafios. É mais fácil encontrar registros quando o biografado foi escravo - e, portanto, legalmente definido como propriedade - do que quando livre. Os desafios são, em geral, ainda maiores quando se busca biografar uma mulher. Se casada, sua identidade legal encontrava-se subsumida à de seu marido. Pessoas escravizadas frequentemente tinham negado seu acesso à alfabetização; por conta disso, quando chegam a existir testemunhos de descendentes de africanos escravizados, esses são, em geral, mediados pelas vozes de escrivães ou comentaristas brancos de confiabilidade questionável. Em consequência, nos raros casos em que se tem acesso direto às vozes de pessoas escravizadas, essas são, por definição, figuras extraordinárias. Mary Walker era excepcionalmente extraordinária. Por exemplo, muito embora nascida e criada como escrava na Carolina do Norte, Mary Walker sabia ler e escrever. Desafortunadamente, entretanto, tem-se notícia apenas de três cartas suas que sobreviveram. As principais bases evidenciais do livro são os documentos da família Cameron, antigos proprietários de Mary Walker; depois, os escritos de seus apoiadores abolicionistas, Susan e Peter Lesley, e o diário da tia de Susan Lesley, Ca- 
therine Robbins. Nathans complementa essas fontes principais com uma miríade de outras.

Repetidamente descrita por observadores contemporâneos como de pele tão clara que quase podia passar por branca, Mary Walker, ao que parece, tinha pai e avô brancos, sendo a mãe e a avó mulheres escravizadas de ascendência africana. O pai de seus três filhos, todos nascidos escravos, era também aparentemente branco. Mary foi criada como uma escrava relativamente privilegiada e de confiança na casa de Duncan Cameron, um fazendeiro rico que mais tarde se tornaria banqueiro na Carolina do Norte. A partir de 1846, por três vezes Duncan levou Mary, na condição de ama de suas filhas, para a Filadélfia, em busca de tratamento médico para a caçula, afligida por uma doença misteriosa que a deixou incapaz de andar sem assistência. Já na primeira viagem, Mary estabeleceu contato com membros da comunidade negra livre da Filadélfia, para junto dos quais fugiu durante sua terceira visita à cidade, em 1848, depois de seu proprietário ter ameaçado mandá-la para o "sul profundo", por razões desconhecidas. Foi habilidosa o bastante para obter declarações confirmando que seu proprietário a tinha trazido voluntariamente ao estado livre da Pensilvânia, anulando, assim, a possibilidade legal de que Cameron a reclamasse como escrava fugitiva. Nathans mostra que essa foi uma das muitas vezes em que Mary demonstrou capacidade e von- tade de agir por si própria. Mas, para libertar-se, teve de deixar para trás sua mãe e seus filhos ainda escravizados na Carolina do Norte. Ela dedicou os dezessete anos seguintes a tentar libertá-los e fazê-los juntar-se a ela na sua jornada rumo ao norte. Nathans observa que "a experiência de Mary Walker espelhava a de outros milhares. Todos os que escaparam do cativeiro deixaram membros da família para trás” (p. 253).

O refúgio que Mary buscara entre os simpatizantes abolicionistas da Filadélfia, onde rapidamente encontrou emprego como costureira, logo foi ameaçado pela promulgação, em nível federal, no ano de 1850, da Lei de Escravos Fugitivos - a qual, segundo a interpretação de um tribunal local, sobrepunha-se à lei do estado da Pensilvânia. Seu empregador terminou por ajudá-la a encontrar trabalho na casa de parentes, Peter Lesley e sua esposa, Susan Lyman Lesley, em Milton, Massachusetts, próximo a Boston, na esperança de enviar Mary para longe do alcance dos caçadores de escravos. Gradualmente, Mary tornou-se a principal cuidadora de um outro membro da família Lesley, Anne Jean Robbins Lyman, a mãe viúva de Susan, uma mulher de trato cada vez mais difícil. Em 1852, os Lesleys se mudaram para a Filadélfia, depois de fracassada a carreira de Peter como pastor protestante em Milton, mas Mary permaneceu em Massachusetts para cuidar de Anne Jean Robbins Lyman. Susan passaria os verões seguintes visitando sua mãe, e suas cartas para o marido 
revelam que ela rapidamente desenvolveu uma estreita amizade com Mary.

Não obstante a sensação de segurança conquistada por Mary Walker, ela foi rapidamente perturbada pelas notícias, no início de 1853, de que seu antigo dono, Duncan Cameron, morrera deixando o destino da mãe e dos filhos dela nas mãos do herdeiro Paul, o qual já havia demonstrado sua vontade de separar as famílias escravas da propriedade. Por intermédio de seus contatos na Filadélfia, ela soube que seu filho mais velho, Frank, fugira do cativeiro em 1852. Ao que parece, ela jamais o viu ou ouviu falar dele novamente. A missão de Mary nos doze anos seguintes seria tentar resgatar ou comprar a liberdade de sua família. Com a ajuda dos Lesleys - cuja oposição à escravidão havia se fortalecido em resposta à Lei de Escravos Fugitivos, ao resultado do caso Dred Scott, em 1857, e, especialmente, devido à sua amizade com Mary —, ela procurou intermediários que pudessem resgatar sua mãe e seus filhos do Sul. Seus esforços, incluindo uma carta de Peter Lesley à filha de Duncan Cameron, não obtiveram sucesso, e todas as tentativas de fuga terminaram pela escalada da vigilância em razão do ataque de John Brown ao arsenal dos Estados Unidos no porto de Harper Ferry, Virgínia, em outubro de 1859.

$\mathrm{O}$ advento da Guerra Civil radicalizou ainda mais as posições de Mary Walker. Seus pontos de vista sobre a escravidão ganharam uma abrangência nacional. Ela chocou a tia de Susan Lesley com sua expectativa de que "seus filhos atacassem primeiro", em vez de esperarem ser emancipados, e com seu desejo de que "seus filhos [...] soubessem como morrer por sua liberdade"" (p. 167, 190). Mary Walker também tornou-se ativa na causa abolicionista, demonstrando sua independência, em 1864, ao se dispor a participar como voluntária, por um curto período, no malfadado projeto, nas ilhas da Carolina do Sul, que pretendia preparar escravos recém-emancipados para a liberdade, episódio detalhado no livro.

$O$ fim da guerra trouxe a liberdade para a filha de Mary Walker, Agnes Walker Burgwyn, já casada e com 28 anos (em outras passagens, Nathans the atribui, equivocadamente, 25 anos), e seu filho de 21 anos de idade, Bryant Walker, que logo se juntaram à mãe em Massachusetts. A mãe de Mary havia morrido. O reencontro obrigou Mary a continuar trabalhando para ajudar a sustentar a família, que cresceu rapidamente quando Bryant casou-se com uma mulher de origem irlandesa em 1866. Logo vieram os netos. Mary Walker morreria em 1872. Nathans rastreia sua descendência até o recente reencontro dos descendentes de Mary Walker e Susan Lesley.

To free a family é uma realização notável em termos metodológicos, prosopográficos e estilísticos. Uma bibliografia e uma árvore genealógica da família teriam tornado o li- 
vro ainda melhor. Embora Nathans empregue com habilidade as técnicas narrativas de um romancista, incluindo suspense no final dos capítulos, e o tipo de discurso indireto livre mais comumente associado a Jane Austen, ele se abstém de recorrer a licenças poéticas, resistindo a todo impulso de argumentar para além da evidência disponível. Como consequência, Nathans muitas vezes especula explicitamente sobre as causas e os motivos por trás das ações. Como ele diz, "o leitor deve decidir se a evidência o convence" (p. 8). Muito poucos leitores não serão persuadidos. O livro revela as relações complexas, frequentemente imprevisíveis e surpreendentemente íntimas entre negros e brancos nos Estados Unidos durante os séculos XIX e XX, apresentando "participações especiais" (p. 5) de grandes personagens do quilate de Lydia Maria Child, Frederick Douglass, Ralph Waldo Emerson, Harriet Jacobs, Henry James, Henry Wadsworth Longfellow e Harriet Beecher Stowe. Em última análise, a jornada que Nathans acompanha não é apenas a de Mary Walker. To free a family abrange jornadas não só das famílias $\mathrm{Ca}$ meron e Lesley, mas também aquela dos Estados Unidos.

Vincent Carretta vcarretta@hotmail.com Universidade de Maryland Tradução de Fábio Baqueiro Figueiredo 